\title{
STUDI EKSPLORASI PERALATAN PRAKTIKUM PROGRAM KEAHLIAN OTOMOTIF DITINJAU DARI STANDAR NASIONAL PENDIDIKAN
}

\author{
Maulana Nugraha ${ }^{1}$, Wowo S. Kuswana ${ }^{2}$, Mumu Komaro ${ }^{3}$ \\ Departemen Pendidikan Teknik Mesin \\ Universitas Pendidikan Indonesia \\ Jl. Dr. Setiabudhi No. 207 Bandung 40154 \\ maulana-nugraha@yahoo.co.id
}

\begin{abstract}
ABSTRAK
Tujuan penelitian ini untuk memperoleh gambaran tentang sarana dan prasarana Teknik Mekanik Otomotif SMK MJPS 1 Tasikmalaya terhadap pemenuhan standar Nasional Pendidikan. Sarana pendidikan adalah semua prangkat peralatan, bahan, dan perabot yang secara langsung digunakan dalam proses pendidikan di sekolah. Prasarana pendidikan adalah semua perangkat kelengkapan dasar yang secara tidak langsung menunjang pelaksanaan proses pendidikan di sekolah. Metode penelitian yang digunakan yaitu metode deskriptif. Hasil penelitian menunjukkan sarana Praktik Mekanik Otomotif sudah memenuhi SNP dengan kategori sangat layak. Prasarana Praktik Mekanik Otomotif sudah memenuhi SNP dengan kategori sangat layak. Sarana dan prasarana yang ada untuk Praktik Mekanik Otomotif dinyatakan telah memenuhi standar uji kompetensi dengan kategori sangat layak.
\end{abstract}

Kata kunci: sarana, prasarana, mekanik, otomotif, standar

\section{PENDAHULUAN}

Setiap satuan pendidikan berusaha untuk mencapai mutu pendidikan yang baik, namun ternyata tidak setiap satuan pendidikan mampu melakukannya. Banyak faktor yang menjadi kendala dan penghambat sehingga tidak mampu mencapainya. Sekolah dan madrasah merupakan pihak yang memberikan pengaruhterbesar terhadap proses dan hasil peningkatan mutu pendidikan. Perbedaan harapan dan kenyataan adalah hal yang menyebabkan terjadinya masalah. Masalah di dunia pendidikan, dapat timbul karena beberapa faktor. Dunia pendidikan mempunyai banyak faktor yang riskan menimbulkan masalah. Pedoman yang digunakan untuk mencapai atau pemenuhan mutu pendidikan pada satuan pendidikan adalah Standar Nasional Pendidikan (SNP) dan standar-standar lain yang disepakati oleh kelompok masyarakat.

Standar nasional pendidikan adalah standar yang dibuat oleh pemerintah. Sedangkan standar lain adalah standar yang dibuat oleh satuan pendidikan dan/atau lembaga lain yang dijadikan acuan oleh satuan pendidikan. Standar lain yang disepakati oleh kelompok masyarakat digunakan setelah SNP dipenuhi oleh satuan pendidikan sesuai dengan kekhasan jalur, jenjang, dan jenis pendidikan.SNP sebagaimana yang diatur dalam Peraturan

\footnotetext{
${ }^{1}$ Mahasiswa Departemen Pendidikan Teknik Mesin FPTK UPI

2 Dosen Departemen Pendidikan Teknik Mesin FPTK UPI

${ }^{3}$ Dosen Departemen Pendidikan Teknik Mesin FPTK UPI
} 
Pemerintah Nomor 19 Tahun 2005 tentang Standar Nasional Pendidikan dan peraturan perundangan lain yang relevan yaitu kriteria minimal tentang sistem pendidikan di seluruh wilayah hukum Negara Kesatuan Republik Indonesia. SNP dipenuhi oleh satuan atau program pendidikan dan penyelenggara satuan atau program pendidikan secara sistematis dan bertahap dalam kerangka jangka menengah yang ditetapkan dalam rencana strategis satuan atau program pendidikan. Penyelenggaraan pendidikan terdapat delapan standar yang harus di laksanakan yaitu: standar isi, standar proses, standar kompetensi lulusan, standar kompetensi pendidik dan tenaga kependidikan, standar sarana dan prasarana, standar pengelolaan, standar pembiayaan, standar penilaian.

Tanggung jawab sekolah dalam menghadapi perkembangan teknologi saat ini adalah mempersiapkan siswa untuk bisa bersaing dalam masyarakat yang sangat cepat perubahannya.Tantangan yang dihadapi para siswa lulusan SMK adalah mempersiapkan tenaga kerja yang memiliki keterampilan dan keahlian dalam bidang teknologi yang berkembang sekarang ini.Apapun alasannya untuk menyambut kenyataan teknologi di dunia ini memang harus dihadapi. Mengingat lulusan SMK di seluruh wilayah nusantara sebagian besar bekerja di dunia usaha dan industri. Dengan adanya teknologi yang telah meluas disegala bidang kehidupan manusia, dibutuhkan kompetensi dan tanggung jawab terhadap sistem pendidikan guna meningkatkan kemahiran akan kompetensi bidang teknologi bagi siswa SMK. Delapan standar yang harus dilaksanakan dalam penyelenggaraan pendidikan penulis memilih salah satu standar yaitu standar sarana dan prasarana karena faktor sarana prasarana ini sangat penting, apalagi di SMK yang memerlukan banyak pratik dalam kegiatan pembelajarannya. Selain itu meningkatnya standar pada ujian praktik kejuruan setiap tahunnya seiring tuntutan dari dunia industri yang semakin maju dengan alat-alat yang semakin canggih. Hal ini terlihat dari instrumen verifikasi SMK penyelenggara ujian praktik kejuruan yang dikeluarkan BNSP tiap tahunnya mengalami peningkatan. Praktik dalam dunia pendidikan tak bisa terlepas dari apa yang disebut sarana prasarana.

Sarana prasara untuk SMK/MAK diatur dalam Peraturan Mentri Pendidikan Nasional nomor 40 tahun 2008. Selain standar Nasional Pendidikan yang harus dipenuhi, ada dalil-dalil lain yang dikeluarkan dalam proses perencanaan sampai pengelolaan sarana dan prasarana praktik SMK. Dalil tentang pendidikan kejuruan antara lain: pendidikan kejuruan akan efisien jika lingkungan dimana siswa dilatih merupakan replika lingkungan dimana nanti ia akan bekerja. Pendidikan kejuruan yang efektif hanya dapat diberikan dimana tugas-tugas latihan dilakukan dengan cara, alat dan mesin yang sama seperti yang ditetapkan di tempat kerja. 
Pendidikan kejuruan akan efektif jika melatih seseorang dalam kebiasaan berpikir dan bekerja seperti yang diperlukan dalam pekerjaan itu sendiri. Pendidikan kejuruan akan efektif jika dapat memampukan setiap individu memodali minatnya, pengetahuannya dan keterampilannya pada tingkat yang paling tinggi. Pendidikan kejuruan yang efektif untuk setiap profesi, jabatan atau pekerjaan hanya dapat diberikan kepada seseorang yang memerlukannya, yang menginginkannya dan yang mendapat untung darinya. Pendidikan kejuruan akan efektif jika pengalaman latihan untuk membentuk kebiasaan kerja dan kebiasaan berpikir yang benar diulang-ulang sehingga sesuai seperti yang diperlukan dalam pekerjaan nantinya. Pendidikan kejuruan akan efektif jika gurunya telah mempunyai pengalaman yang sukses dalam penerapan keterampilan dan pengetahuan pada operasi dan proses kerja yang akan dilakukan. Pada setiap jabatan ada kemampuan minimum yang harus dipunyai oleh seseorang agar dia tetap dapat bekerja pada jabatan tersebut. Pendidikan kejuruan harus memperhatikan permintaan pasar. Proses pembinaan kebiasaan yang efektif pada siswa akan tercapai jika pelatihan diberikan pada pekerjaan yang nyata (pengalaman sarat nilai). Sumber yang dapat dipercaya untuk mengetahui isi pelatihan pada suatu okupasi tertentu adalah dari pengalaman para ahli okupasi tersebut. Setiap pekerjaan mempunyai ciriciri isi (body of content) yang berbeda-beda antara satu dengan yang lain. Pendidikan kejuruan akan merupakan layanan sosial yang efisien jika sesuai dengan kebutuhan seseorang yang memang memerlukan dan memang paling efektif jika dilakukan lewat pengajaran kejuruan. Pendidikan kejuruan akan efisien jika metode pengajaran yang digunakan dan hubungan pribadi dengan peserta didik mempertimbangkan sifat-sifat peserta didik tersebut. Administrasi pendidikan kejuruan akan efisien jika luwes. Pendidikan kejuruan memerlukan biaya tertentu dan jika tidak terpenuhi maka pendidikan kejuruan tidak boleh dipaksakan beroperasi.

Kebutuhan akan sarana dan prasarana pada SMK menjadi kebutuhan yang sangat penting dan akan mengakibatkan terganggunya proses pembelajaran jika sarana dan prasarana tersebut tidak sesuai dengan standar yang telah ditetapkan. Untuk mengetahui apakah standar sarana prasarana untuk SMK/MAK yang telah ditetapkan oleh pemerintah yang diatur dalam Peraturan Mentri Pendidikan Nasional nomor 402008 Telah memenuhi atau belum, maka perlu dilaksanakan observasi.Untuk mengetahui apakah standar sarana prasarana untuk SMK/MAK yang telah ditetapkan oleh pemerintah yang diatur dalam Peraturan Menteri Pendidikan Nasional nomor 402008 telah memenuhi atau belum. 
Sarana pendidikan dapat diklasifikasikan menjadi tiga macam, yaitu berdasarkan habis tidaknya, berdasarkan bergerak tidaknya, dan berdasarkan hubungan dengan proses pembelajaran. Apabila dilihat dari bergerak atau tidaknya pada saat pembelajaran juga ada dua macam, yaitu bergerak dan tidak bergerak. Sementara jika dilihat dari hubungan sarana tersebut terhadap proses pembelajaran ada tiga macam, yaitu alat pelajaran, alat peraga, dan media pembelajaran.

Sarana pendidikan yang habis pakai merupakan bahan atau alat yang apabila digunakan dapat habis dalam waktu yang relatif singkat. Misalnya, kapur tulis, tinta printer, kertas tulis, dan bahan-bahan kimia untuk praktik. Ada pula sarana pendidikan yang berubah bentuk, misalnya kayu, besi, dan kertas karton yang sering digunakan oleh guru dalam mengajar. Selain itu, sarana pendidikan tahan lama adalah bahan atau alat yang dapat digunakan secara terus menerus atau berkali-kali dalam waktu yang relatif lama. Sarana pendidikan yang bergerak merupakan sarana pendidikan yang dapat digerakkan atau dipindah-tempatkan sesuai dengan kebutuhan para pemakainya. Contohnya meja dan kursi, almari arsip, dan alat-alat praktik. Kemudian, untuk sarana pendidikan yang tidak bergerak adalah sarana pendidikan yang tidak dapat dipindahkan atau sangat sulit jika dipindahkan. Hubungannya dengan proses pembelajaran tersebut, sarana pendidikan dapat dibedakan menjadi tiga, yaitu alat pelajaran, alat peraga, dan media pengajaran. Alat pelajaran adalah alat yang dapat digunakan secara langsung dalam proses pembelajaran, misalnya buku, alat peraga, alat tulis, dan alat praktik. Alat peraga merupakan alat bantu pendidikan yang dapat berupa perbuatan-perbuatan atau benda-benda yang dapat mengkonkretkan materi pembelajaran. Materi pembelajaran yang tadinya abstrak dapat dikonkretkan melalui alat peraga sehingga peserta didik lebih mudah dalam menerima pelajaran. Media pengajaran adalah sarana pendidikan yang berfungsi sebagai perantara (medium) dalam proses pembelajaran sehingga meningkatkan efektivitas dan efisiensi dalam mencapai tujuan pendidikan. Media pengajaran ada tiga jenis, yaitu visual, audio, dan audio visual (Barnawi \& Arifin, 2012).

Prasarana pendidikan merupakan penunjang proses pendidikan di sekolah, seperti sarana yang telah dijelaskan sebelumnya. Prasarana pendidikan di sekolah dapat diklasifikasikan menjadi dua macam, yaitu prasarana langsung dan prasarana tidak langsung. Prasarana langsung adalah prasarana yang secara langsung digunakan dalam proses pembelajaran, misalnya ruang kelas, ruang laboratorium, ruang praktik, dan ruang komputer. Prasarana tidak langsung adalah prasarana yang tidak digunakan dalam proses pembelajaran, 
tetapi sangat menunjang proses pembelajaran, misalnya ruang kantor, kantin, tanah, dan jalan menuju sekolah, kamar kecil, ruang UKS, ruang guru, ruang kepala sekolah, taman, dan tempat parkir kendaraan (Arum, 2007). Setiap jenjang pendidikan memliki standar sarana prasarana tertentu, adapun badan yang mengatur standar tersebut adalah Badan Standar Nasional Pendidikan (BSNP).

BSNP adalah badan mandiri dan independen yang bertugas mengem-bangkan, memantau pelaksanaan, dan mengevaluasi standar nasional pendidikan. BSNP 1289-P2-15/16 yaitu Standar yang dikeluarkan oleh BSNP tentang sebuah Instrumen Verifikasi SMK Penyelenggara Ujian Praktek Kejuruan untuk Jurusan Teknologi Kendaraan Ringan. Instrument ini di dalamnya terdapat beberapa standar yaitu: (1) Standar persyaratan peralatan utama; (2) Standar persyaratan peralatan pendukung; (3) Standar persyaratan tempat/ruang; dan (4) Persyaratan penguji.

Uji kompetensi adalah suatu sarana untuk menguji kemampuan siswa apakah siswa ini kompeten atau tidak kompeten di dalam mata diklat yang telah diberikan. Pembelajaran berbasis kompetensi adalah pembelajaran yang dilakukan dengan orientasi pencapaian peserta didik, sehingga muara akhir hasil pembelajaran adalah meningkatnya kompetensi peserta didik yang dapat diukur dalam pola sikap, pengetahuan, dan keterampilannya. Kompetensi merupakan evalusi hasil belajar siswa selama belajar dan bisa dijadikan sebagai alat ukur keberhasilan siswa dan guru dalam melaksanakan pembelajaran di sebuah sekolah.

\section{METODE PENELITIAN}

Metode yang digunakan pada penelitian ini adalah metode deskriptif. Tujuan dari penelitian deskriptif ini adalah untuk membuat deskripsi, gambaran atau lukisan secara sistematis, faktual dan akurat mengenai fakta-fakta, sifat-sifat serta hubungan antar fenomena yang diselidiki. Penelitian dengan pendekatan kuantitatif dilakukan sebagai cara untuk meneliti berbagai aspek dari pendidikan.

\section{HASIL PENELITIAN}

Hasil penelitian yang beberapa aspek antara lain: prasarana praktik, sarana di area kerja engine otomotif, sarana di area kerja kelistrikan otomotif, sarana di area kerja chassis dan pemindah tenaga, sarana di area instruktur dan tempat penyimpanan, persyaratan alat utama uji kompetensi, persyaratan alat pendukung uji kompetensi, persyaratan penguji 
internal uji kompetensi, persyaratan penguji eksternal, dan persyaratan tempat/ruang uji kompetensi.

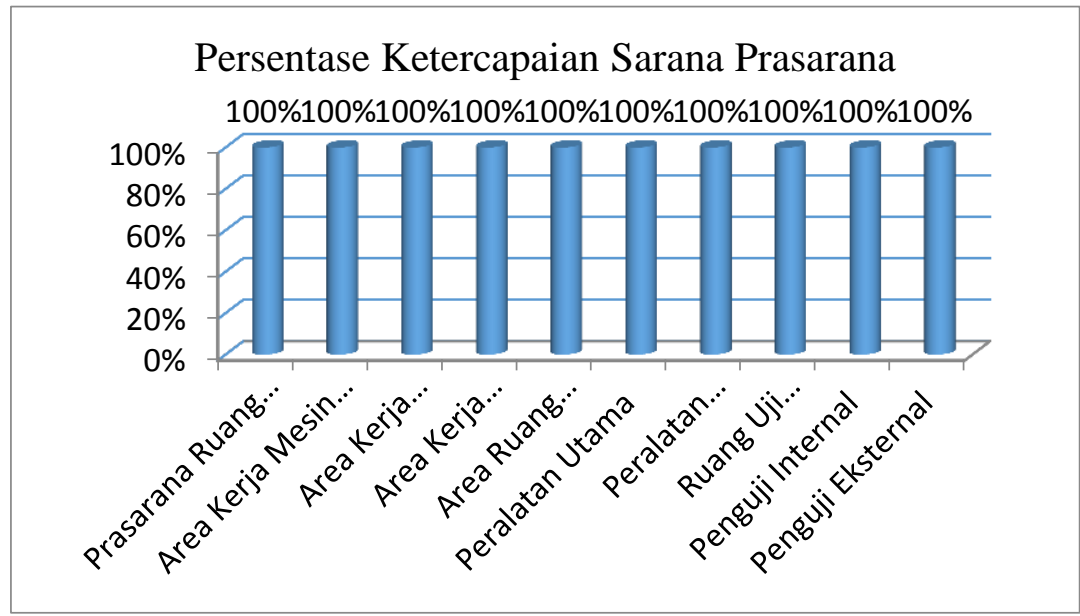

Gambar 1. Sarana prasarana ruang praktikotomotif SMK MJPS 1 Tasikmalaya.

\section{PEMBAHASAN}

Hasil data di lapangan yang disesuaikan dengan standar yang ada dan dari hasil observasi dan dokumentasi. Pencapaian standar sarana pada area kerja mesin otomotif mencapai $100 \%$. Artinya tingkat ketercapaian untuk standar sarana di area kerja mesin tomotif dinyatakan sangat layak/sangat lengkap yang disesuaikan terhadap Peraturan Menteri Pendidikan Nasional Nomor 40 Tahun 2008 Tentang Standar Sarana dan Prasarana Sekolah Menengah Kejuruan/Madrasah Aliyah Kejuruan.

Pencapaian standar sarana pada area kerja kelistrikan otomotif mencapai $100 \%$. Artinya tingkat ketercapaian untuk standar sarana di area kerja kelistrikan otomotif dinyatakansangat layak/ sangat lengkap yang disesuaikan terhadap Peraturan Menteri Pendidikan Nasional Nomor 40 Tahun 2008 Tentang Standar Sarana dan Prasarana Sekolah Menengah Kejuruan/Madrasah Aliyah Kejuruan. Kondisi sarana pada area kerja kelistrikan otomotif bisa dikatakan layak/lengkap dan bisa menimbulkan hasil yang positif terhadap hasil belajar siswa.

Pencapaian standar sarana pada area kerja chassis dan pemindah tenaga di praktik otomotif mencapai $100 \%$. Artinya tingkat ketercapaian untuk standar sarana di area kerja chassis dan pemindah tenaga otomotif dinyatakan sangat layak/sangat lengkap yang disesuaikan terhadap Peraturan Menteri Pendidikan Nasional Nomor 40 Tahun 2008 Tentang Standar Sarana dan Prasarana Sekolah Menengah Kejuruan/Madrasah Aliyah Kejuruan. 
Kondisi sarana pada area kerja chassis dan pemindah tenaga bisa dikatakan sangat layak/sangat lengkap dan bisa menimbulkan hasil yang positif terhadap hasil belajar siswa.

Pencapaian standar sarana pada ruang penyimpanan dan instruktur di praktik otomotif mencapai $100 \%$. Artinya tingkat ketercapaian untuk standar sarana di ruang penyimpanan dan instruktur praktik otomotif dinyatakan sangat layak/sangat lengkap yang disesuaikan terhadap Peraturan Menteri Pendidikan Nasional Nomor 40 Tahun 2008 Tentang Standar Sarana dan Prasarana Sekolah Menengah Kejuruan/Madrasah Aliyah Kejuruan. Hasil tersebut menunjukkan bahwa sarana pada ruang penyimpanan dan instruktur sangat layak/sangat lengkap dan sangat memadai untuk dilakukannya proses belajar mengajar dan mendukung meningkatnya proses belajar mengajar.

Secara keseluruhan hasil dari observasi dan dokumentasi di atas menjelaksan bahwa sarana pada area kerja mesin otomotif, sarana pada area kerja kelistrikan otomotif, sarana pada area kerja chassis dan pemindah tenaga, serta sarana pada ruang penyimpanan dan instruktur dinyatakan sangat layak/sangat lengkap dan sangat memadai untuk dilakukannya proses belajar mengajar dan mendukung meningkatnya proses belajar mengajar.

Pencapaian standar prasarana ruang praktik di praktik otomotif mencapai $100 \%$. Artinya tingkat ketercapaian untuk standar prasarana di praktik Otomotif dinyatakansangat layak/sangat lengkap yang disesuaikan terhadap Peraturan Menteri Pendidikan Nasional Nomor 40 Tahun 2008 Tentang Standar Sarana dan Prasarana Sekolah Menengah Kejuruan/Madrasah Aliyah Kejuruan. Hasil tersebut menunjukkan bahwa prasarana ruang praktik kurang memadai untuk dilakukannya proses belajar mengajar dan mendukung meningkatnya proses belajar mengajar.

Pencapaian standar peralatan utama uji kompetensi praktik otomotif mencapai $100 \%$. Artinya untuk ketercapaian standar peralatan utama uji kompetensi di praktik Otomotif dinyatakan sangat layak dengan mendapat skor 3yang disesuaikan terhadap Instrumen Verifikasi SMK Penyelenggara Ujian Praktik Kejuruan dari BSNP.

Pencapaian standar peralatan pendukung uji kompetensi praktik otomotif mencapai $100 \%$. Artinya tingkat ketercapaian untuk standar peralatan pendukung uji kompetensi praktik otomotif dinyatakan sangat layak dengan mendapat skor 3 yang disesuaikan terhadap Instrumen Verifikasi SMK Penyelenggara Ujian Praktik Kejuruan dari BSNP.

Pencapaian standar persyaratan tempat/ruang uji kompetensi praktik otomotif mencapai $100 \%$. Artinya tingkat ketercapaian untuk standar persyaratan tempat/ruang uji kompetensi praktik otomotif dinyatakan sangat layak dengan mendapat skor 3 yang 
disesuaikan terhadap Instrumen Verifikasi SMK Penyelenggara Ujian Praktik Kejuruan dari BSNP.

Pencapaian standar persyaratan penguji internal uji kompetensi praktik otomotif mencapai $100 \%$. Artinya tingkat ketercapaian untuk standar persyaratan penguji internal uji kompetensi di praktik otomotif dinyatakan sangat layak dengan mendapat skor 3 yang disesuaikan terhadap Instrumen Verifikasi SMK Penyelenggara Ujian Praktik Kejuruan dari BSNP.

Pencapaian standar persyaratan penguji eksternal uji kompetensi praktik otomotif mencapai $100 \%$. Artinya tingkat ketercapaian untuk standar persyaratan penguji eksternal uji kompetensi di praktik Otomotif dinyatakan sangat layak dengan mendapat skor 3 yang disesuaikan terhadap Instrumen Verifikasi SMK Penyelenggara Ujian Praktik Kejuruan dari BSNP (BSNP, 2015). Sarana dan prasarana yang terdapat di ruang Praktik Teknik Mekanik Otomotif SMK MJPS 1 Tasikmalaya bisa memenuhi standar uji kompetensi dengan ketercapaian $100 \%$ yang artinya sangat layak untuk dijadikan tempat pelaksanaan ujian kompetensi.

Lingkungan fisik tempat belajar mempunyai pengaruh penting terhadap hasil pembelajaran. Lingkungan fisik yang menguntungkan dan memenuhi syarat minimal mendukung meningkatnya intensitas proses pembelajaran dan mempunyai pengaruh positif terhadap pencapaian tujuan pengajaran. Lengkap tidaknya perlengkapan belajar baik yang dimiliki siswa maupun yang dimiliki sekolah menimbulkan hasil tertentu terhadap hasil belajar siswa. Kekurangan peralatan dapat membawa akibat negatif antara lain siswa tidak bisa belajar secara baik sehingga sulit diharapkan mencapai prestasi tinggi (Bafadal, 2008). Kondisi sarana pada area kerja mesin otomotif bisa dikatakan sangat layak/sangat lengkap dan bisa menimbulkan hasil yang positif terhadap hasil belajar siswa.

\section{KESIMPULAN}

Kesimpulan penelitian ini sebagai berikut: sarana dan prasarana praktik mekanik otomotif yang ada sekarang dinyatakan sudah memenuhi standar nasional. Artinya termasuk kepada katagori sangat layak/sangat lengkap. Sarana dan prasarana yang ada untuk praktik Mekanik Otomotif dinyatakan telah memenuhi standar uji kompetensi. Artinya sangat lengkap/sangat layak untuk dijadikan tempat pelaksanaan ujian kompetensi yang disesuaikan terhadapInstrumen Verifikasi SMK Penyelenggara Ujian Praktik Kejuruan dari BSNP. 


\section{DAFTAR PUSTAKA}

Arikunto, S. (2003). Organisasi dan administrasi pendidikan Teknologi dan Kejuruan. PT Grapindo Persada: Jakarta.

Arum, W. S. A. (2007). Manajemen Sarana dan Prasarana Pendidikan. Jakarta: CV. Multi Karya Mulia.

Bafadal, I. (2008). Manajemen Perlengkapan Sekolah Teori dan Aplikasi. Jakarta: Bumi Aksara.

Barnawi \& Arifin, M. (2012). Manajemen Sarana dan Prasarana Sekolah. Jogjakarta: ArRuzz Media.

BSNP. (2015). Instrumen Verifikasi Smk Penyelenggara Ujian Praktik Kejuruan. Kemdikbud. 